\title{
The Influence of Intellectual Capital with Sub Components to Financial Performance: Empirical Study of Islamic Banking in Indonesia
}

\author{
Toufan Aldian Syah \\ Doctoral Program, \\ IAIN Purwokerto, Indonesia
}

\author{
Akhmad Fauzan \\ Lecturer of Postgraduate Program, \\ IAIN Purwokerto, Indonesia
}

\begin{abstract}
This paper aims to empirically examine the effect of intangible resources, namely intellectual capital (IC) on the financial performance of Islamic banking in Indonesia for the period 2013-2019. The data needed to calculate the different IC constituents comes from the financial statement data of each Islamic bank, which is the research sample, namely the Islamic bank, which is a foreign exchange bank. Value Added Intellectual Coefficient (VAIC) The methodology designed by Pulic is used to determine the impact of IC on Islamic banking's financial performance. The results show a significant positive relationship between the Sub-component Value Added Intellectual Coefficient (VAIC), namely Human Capital Efficiency (HCE), Structure Capital Efficiency (SCE), and Capital Employed Efficiency (CEE) which have a significant influence on the financial performance of Islamic banking proxied by ROA. Overall, the results show that HCE, SCE, and CEE strongly influence Islamic banks' ability to earn profits. The main limitation of this study lies in its measurement method, the VAIC methodology, which has been criticized by some researchers as not measuring IC. These findings can be useful input for Islamic bank management to manage and invest their resources in the Intellectual Capital (IC) in their institution. The main contribution of this paper is to identify the influence of the subcomponent of intellectual capital (IC) on the financial performance of Islamic banks, which was previously rare in Indonesia.
\end{abstract}

Keywords:- Intellectual Capital; iB-VAIC; Financial Performance; Islamic Bank.

\section{INTRODUCTION}

The growth of sharia banking assets in Indonesia shows a significant development, namely the Financial Services Authority recorded an increase in sharia banking assets in October 2019 of 10.15 percent (YoY), an increase from Rp 477 trillion in 2018 to Rp 513 trillion. (Indonesian Banking Statistics, 2019) An increase also occurred in the market share of the Islamic banking industry in the national banking industry. The market share growth compared to the share of sharia banks in the banking industry, which had reached $6.01 \%$ as of October 2019, according to the Financial Services Authority data or reached Rp 513 trillion. In detail, this achievement is the highest in history and increased from the beginning of 2019 to September 2019 at $5.94 \%$. (Mediatama, 2019)

Statistical data shows that the condition of domestic sharia banking is quite good. However, there are significant challenges that must be faced, among others, the scale of sharia bank assets are generally small relative, there are only two sharia banks with asset sizes above Rp 40 trillion, and the focus of services provided is also still limited in the retail segment including MSMEs and consumers. (SPS December 2018, 2018) While at the ASEAN level, such as Malaysia, there is more than one Islamic bank with an asset scale above Rp 175 trillion, with a more varied service segment and more efficient operations. At the end of 2019, even the entire Sharia banking assets in Malaysia reached Rp. 2,789 Trillion. (Malaysian Sharia Banking Assets Reaches IDR 2,789 Trillion, 2020)

At the end of 2018, Return on Assets (ROA) of Commercial Banks was at $1.65 \%$, while Sharia Commercial Banks struggled at $1.26 \%$. (Indonesian Banking Statistics, 2019) This was also supported by research conducted by Trad, Trabelsi, \& Goux (2017), where the results obtained in this study lead to the conclusion that the Islamic financial system cannot be a substitute for conventional methods, but rather a commercial supplement for traditional methods. (Trad et al., 2017, p. 45)

Fluctuations in the value of return on assets (ROA), which is a proxy of financial performance in Islamic banks, shows the results where the average cost of ROA during the period January 2013 to December 2018 amounted to $1.28 \%$. Whereas ROE from 2013 was at $25 \%$, continued to decline to $11 \%$ in 2018 . And the average ROA movement in Islamic banks also declined from year to year.

Bank Financial Performance is an illustration of the extent of the success achieved by banks in their operations. (Wahyuni \& Sukartha, 2019, p. 391) Banking financial performance is a significant factor and is very important to assess overall performance. Financial ratio analysis is used by management to identify banks' success in carrying out their operational activities. Financial ratio analysis can also help business people to assess bank performance. 
Several studies conducted to test the determinants of banking financial performance have been conducted, and there are studies with consistent results, including research by Hadrice (2015), Masood (2015) and Chowdury (2015) showing that the Inflation variable has a positive effect on the financial performance of Islamic banks. Unemployment rate variables in the research of Samhan \& Al-Khatib (2015), Duraj \& Moci (2015) have a significant negative effect on banks' financial performance. Liquidity variables in the research Abdillah (2016) and Chowdury (2015) did not significantly influence Islamic banks' financial performance. Variable Financing for profit sharing and Financing for sale and purchase in research Nurmawati (2019) has a positive effect on Islamic banking's financial performance. Other consistent variables were revealed in studies from Masood (2015), Hadriche (2015), and Abdillah et al. (2016), which is an internal bank factor, namely, Size, BOPO, and CAR has a positive effect on company performance.

From some of the results of the study, there is also one variable that is not consistent, among others, the Intellectual Capital (IC) variable in the study of Shezadi et al. (2018) and Nurmawati (2020). So far, various literature shows that Intellectual Capital is usually understood to consist of human Intellectual Capital, creative Intellectual Capital, and structural Intellectual Capital or organizations comprised of best practices. (Chen et al., 2004) Murthy and Mouritsen (2011) argue that each - each element of Intellectual Capital, namely, Human Capital and Structure Capital, has a weak identity and relationship. Therefore, Intellectual Capital only has limited individual strength to increase creativity or to provide maximum efficiency. Therefore, research needs to be conducted to measure the contribution of each Intellectual Capital sub-component, namely Human Capital (HC), Structure Capital (SC), and Capital Employed (CE) on financial performance measured separately. (Murthy \& Mouritsen, 2011)

\section{LITERATURE REVIEW}

\section{A. Agency Theory}

Jensen and Meckling (1976) state that there are two types of agency relationships, namely between managers and shareholders and between managers and lenders. The agency relationship's essence is the separation between ownership (principal/investor) and control (agent/manager). Ownership is represented by investors who delegate authority to agents; in this case, the manager to manage investor wealth. Investors have the hope that by delegating management authority, they will benefit from increased investor wealth and prosperity. (Kusuma \& Rosyadi, 2019, p. 166)

\section{B. Stakeholder Theory}

According to Freeman, stakeholders are defined as any group or individual that can influence or be influenced by the achievement of organizational goals. Stakeholder theory provides an overview of which parties the company is responsible for. The company must maintain relationships with its stakeholders by accommodating the desires and needs of its stakeholders, especially stakeholders who have the power to the availability of resources used for operational activities of the company, for example, labor, markets for company products, and others. The emergence of stakeholder theory as a dominant paradigm further strengthens the concept that companies are responsible not only to shareholders but also to stakeholders (Freeman, 1999, p. 234)

\section{Resource Based Thery}

Resources Based Theory is a theory that discusses the resources owned by the company and how the company can process and utilize its resources. The company's ability to manage its resources properly can create competitive advantage so that it can create value for the company. RBT serves as the main idea in defining what underlies a company's competitive advantage and financial performance. RBT explains that creating a sustainable competitive advantage is closely related to the company's ability to maintain valuable, rare, and irreplaceable resources, as well as to optimize these resources effectively (Barney, 1991).

Kozlenkova et al. (2014) explain that the underlying logic of this theory is based on two assumptions about company resources. It also explains how these resources can create a sustainable competitive advantage and why some companies can consistently excel from other companies. First, firms have different sets of resources, even within the same industry (Peteraf and Barney, 2003). The assumption regarding the heterogeneity of these resources shows that some companies have a better ability to complete certain activities because they have unique resources (Peteraf and Barney, 2003). Second, resource disparities will persist because difficulties in the exchange of resources between firms (assuming resource immobility) will lead to gains from this heterogeneity of resources.

\section{Financial Performance}

Financial performance is an activity of analyzing to see how a company has used the rules of commercial implementation correctly and adequately. Financial performance is one of the benchmarks that can be used to determine the success of a company is running its business. (Wahyuni \& Sukartha, 2019, p. 391) Profitability is believed to be one of the most appropriate indicators for measuring a company's financial performance. The higher the profitability, the better the financial performance of the company. (Sudana, 2019, p. 25) Bank Indonesia states that there are three ratios used as parameters of bank profitability, namely return on assets (ROA), return on equity (ROE), and net interest margin (NIM).

According to Brigham and Houston (2001), returns on total assets (ROA) are calculated by comparing net income available to ordinary shareholders with total assets. ROA is the net income available to ordinary shareholders of total assets. The higher the value of ROA, the better the company's performance is because, the higher the rate of return on investment. This value reflects the company's profit from all assets (or funding) given to the company (Subramanyam \& Wild, 2010, p. 133) 


\section{E. Intellectual Capital}

Several researchers have defined intellectual capital, including Stewart (1997), which defines intellectual capital as a combination of all useful objects or people that can provide competitive market value in the form of knowledge, information, intellectual property, and experience that can create wealth for the company.

In the theory of resources (Resource-based Theory) states Intellectual Capital meets the criteria as a unique resource to create a competitive advantage for the company to create value for the company, so it can be concluded that if the company succeeds in making maximum use of Intellectual Capital, the company will obtain sustainable profits. (Mavridis, 2004) In his research, Nawas (2019) concluded that Intellectual Capital is considered to be able to increase company profits, where the company's profits are influenced by innovation and intensive knowledge. (Nawaz, 2019, p. 97) This inline with research conducted by Budiasih (2015) (Budiasih, 2015) and Nurmawati (2020), wherein my research, it was found that Intellectual Capital had a positive and significant effect on bank profitability in Indonesia. But in other research conducted by Shehzadi et al. (2018), no influence was found between Intellectual Capital and bank financial performance.

iB-VAIC indicates an organization's intellectual ability, which can also be considered a BPI (Business Performance Indicator). $\mathrm{iB}-\mathrm{VAIC}$ is the sum of the three previous components, namely iB-VACA, iB-VAHU, and iB-STVA.

\section{$i B-V A I C=i B-V A C A+i B-V A H U+i B-S T V A$}

\section{F. HIPOTHESIS}

\section{1) Effect of Human Capital Efficiency on Financial Performance}

Like other companies, human capital is also essential in the financial services sector. Because it is the human touch that encourages and convinces someone to put their money in the bank. Banks offer excellent customer service both directly and through various sources keeping their clients banking with them. The client base of Islamic banks is somewhat different as they choose banks according to their religious beliefs. Therefore, Human Capital Efficiency is of utmost importance in the Islamic banking and finance industry as it represents an efficient delivery of services and media to satisfy client needs.

Empirical evidence regarding the effect of Human Capital Efficiency on the financial performance of Islamic banks can be found in research (Nawas, 2019). Therefore, human capital efficiency is expected to have a significant positive relationship with financial performance. Based on the research results presented earlier, the hypothesis proposed in this study is as follows:

\section{Hypothesis 1: Human Capital Efficiency has a positive influence on financial performance.}

\section{2) Effect of Structure Capital Efficiency on Financial Performance}

Organizations lease human capital resources, but they have structural resources reflected and affirmed in their wealth reports. These resources are significant for doing business. (Nawaz, 2019; Nawaz \& Haniffa, 2017) On the one hand, Structural Capital helps employees to work better and increase their efficiency. Conversely, structural capital increases its efficiency by being used efficiently by human resources. This efficiency is expected to be related to financial performance.

Hsu and Wang (2012) suggest that structural capital, such as operational procedures, knowledge management processes, and organizational profiles, are organizational value creation activities that will positively impact their performance. (Hsu \& Wang, 2012) Companies require advanced technology to compete in today's fast-moving economy, and more excellent care is required to manage structural capital so that the required levels of performance can be achieved. Based on the research results presented earlier, the hypothesis proposed in this study is as follows:

\section{Hypothesis 2: Structure Capital Efficiency has a positive influence on financial performance}

\section{3) Effect of Capital Employed Efficiency on Financial Performance.}

Banking institutions are closely related to money, and they make a profit with the available money. Therefore, physical and financial capital, referred to as the efficiency of capital, is used very significantly for the banking business. Islamic banks operate on an interest-free system; hence profits are mainly generated through various investment and trade projects. They are not relying on interest income like the conventional banking system in Indonesia. Therefore, it is essential to measure the impact of the efficient use of capital on financial performance. (Nawaz, 2019) An empirical study on the effect of Capital Employed Efficiency was conducted (Nawaz, 2019), but in his research, there was no influence between the CEE variables and financial performance. Based on the research results described previously, the hypothesis proposed in this study are as follows:

\section{Hypothesis 3: Capital Employed Efficiency has a positive effect on financial performance.}




\section{EQUATION AND RESEARCH METHODS}

\section{A. Equation}

Financial Performance $=\alpha+\beta 1 H C E+\beta 1 S C E+\beta 3 C E E$ $+e$

\section{B. Research Models}

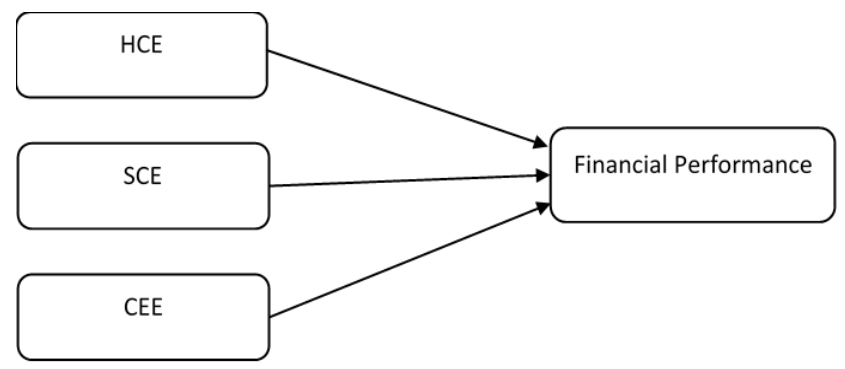

\section{Research Methode}

This type of research is quantitative research. This study is to examine the effect of Intellectual Capital (as measured by $i B-V A I C$ ) and its Sub Components namely Value-Added Capital Employee (iB-VACA), Value Added Human Capital (iB-VAHU), Structural Capital Value Added (iB-SCVA) to financial performance as measured by ROA (Return On Assets).

\section{Population and Sample}

The population used in this study is the financial statements of Sharia Foreign Exchange Commercial Banks in Indonesia, amounting to 5 banks in the 2013-2019 period.

This research sample is the Annual Financial Statements for seven years starting in 2014 until 2019, namely as many as 35 samples, each of the Islamic banks as many as seven annual reports. Sampling uses a purposive sampling method with sampling criteria used is the Sharia Foreign Exchange Commercial Bank registered with OJK which has a complete annual financial report of 5 Sharia Foreign Exchange Commercial Banks, including the Bank Muamalat Indonesia Financial Statements, Bank BNI Syariah Financial Statements, Financial Statements Bank Syariah Mandiri, Bank Syariah Mega Indonesia financial statements, and Bank Maybank Syariah Indonesia financial reports.

\section{E. Dependent Variable}

In this study, the dependent variable is Islamic banks' financial performance as measured by the Return on Asset (ROA) indicator. If the net profit after tax is divided by total assets and multiplied by 100 , the ratio is known as return on assets. Many researchers use return on assets (ROA) to measure a company's financial performance: (Malik, 2015, p. 20)

$$
\mathrm{ROA}=\frac{\mathrm{Net} \text { Profit }}{\text { Total Asset }}
$$

\section{F. Independent Variable}

There are 3 (three) independent variables that will be tested in this study, namely:

\section{1) HCE (Human Capital Efficiency)}

iB-VAHU shows how much iB-VA can be generating with funds spent on labor. This ratio shows the contribution made by each rupiah invested in $\mathrm{HC}$ to the value-added organization.

$$
i B-V A H U=\frac{V A}{H C}
$$

\section{2) SCE ( Structure Capital Efficiency)}

The indicator for measuring Structure Capital Efficiency is by using iB-STVA. iB-STVA shows the contribution of Structure Capital in value creation. iB-STVA measures the amount of SC needed to generate one rupiah from iB-STVA and is an indication of how successful SC is in value creation.

$$
i B-S T V A=\frac{S C}{V A}
$$

3) CEE (Capital Employed Efficiency)

Value Added Capital Employed (iB-VACA). iBSTVA is an indicator of $\mathrm{iB}-\mathrm{VA}$, which is created by one unit of human capital. This ratio shows the contribution made by each unit of $\mathrm{CE}$ to the value-added of the company.

$$
i B-V A C A=\frac{V A}{C E}
$$

\begin{tabular}{|c|c|c|c|c|}
\hline Variable & HCE & SCE & CEE & ROA \\
\hline Mean & 4,008 & 1,076 & 2,528 & 0,029 \\
\hline Maximum & 10,65 & 6,911 & 2,528 & 0,224 \\
\hline Minimum & 0,301 & 0,182 & 0,123 & 0,0006 \\
\hline Std. Dev & 2,380 & 1,211 & 0,569 & 0,0589 \\
\hline $\mathbf{N}$ & 35 & 35 & 35 & 35 \\
\hline
\end{tabular}

\section{RESULT}

\section{A. Descriptive analysis}

Table. 1

Source: SPSS 21 Data Output, processed August 5, 2020

Pada tabel 1 di atas menunjukkan mean, standar deviasi, nilai maksimum dan minimum. Berarti ukuran, utang ke ekuitas, dan pinjaman bermasalah adalah, masingmasing $18,74,13,47$ dan 0,13 . Standar deviasi masingmasing adalah $1,3,30,74$ dan 0,11 . Nilai minimum rata-rata return on asset (ROA) adalah $-0,07$ dan nilai maksimum adalah 0,04. Total 35 pengamatan digunakan untuk mendapatkan hasil. 


\section{B. Classic Assumption Test}

\begin{tabular}{|c|c|c|}
\hline \multicolumn{3}{|c|}{ Classic Assumption Test } \\
\hline $\begin{array}{c}\text { Kolmogorov Smirnov- } \\
\text { Test }\end{array}$ & $\begin{array}{c}\text { Asymp.sig. (2- } \\
\text { tailed) }\end{array}$ & $\mathbf{0 , 0 9 3}$ \\
\hline Durbin Watson & & 1,573 \\
\hline VIF & HCE & 1.117 \\
& SCE & 1.101 \\
& CEE & 1.058 \\
\hline
\end{tabular}

Table. 2:- Test normality, autocorrelation and multicolonierity, Source: SPSS 21 Data Output, processed August 5, 2020

The results of the classic assumption test for this model can be seen in table 2. The normality test in the second model can be seen based on the output of the Kolmogorov-Smirnov test and produces an Asymp value. The Sig (2-tailed) is 0.093 . This value is more significant than 0.05 or $5 \%$, so it can conclude that it is normal. The Durbin Watson value of 1.573 is in an area free of autocorrelation. The results of the multicollinearity test showed that the average VIF value was above one and less than 10 , which indicates that the regression model is freed from multicollinearity between the independent variables.

\section{Multiple Linear Regression Analysis}

The results of multiple linear regression analyses can be seen in the table below.

\begin{tabular}{|c|c|c|c|c|}
\hline Variable & HCE & SCE & \multicolumn{2}{|c|}{ CEE } \\
\hline Coeficient & $-0,050$ & 0,013 & 0,018 \\
\hline t-Statistic & $-3,321$ & 3,649 & \multicolumn{2}{|c|}{2,633} \\
\hline R-Squared & 0,413 & & & \\
\hline F-Statistic & 7,281 & & & \\
\hline
\end{tabular}

Table 4.3:

Source: SPSS 21 Data Output, processed August 5, 2020

This model shows the results of the regression analysis with ROA as the dependent variable. Human Capital Efficiency (HCE) has a significant effect on a negative relationship direction. Meanwhile, the Structure Capital Efficiency (SCE) and Capital Employed Efficiency (CEE) components have a significant effect in a positive direction. The t-stat value, HCE -3,321, SCE 3.649 and CEE 2,633.

The feasibility test of the model seen from the $\mathrm{R}$ squared value is 0.413 , and the simultaneous test with the Fstatistic value is 7.281 . These results reflect that the model built is feasible and meets the criteria.

\section{DISCUSSION}

Based on the results of research that has been done on the effect of Human Capital Efficiency (HCE), Structure Capital Efficiency (SCE), and Capital Employed Efficiency (CEE) on the financial performance of Islamic banking, which is proxied by Return On Asset (ROA). The research results were obtained as follows.

\section{A. Effect of Human Capital Efficiency on Financial Performance}

As explained in the resource-based theory, the main strength needed by a company to obtain maximum performance is to maximize the potential of its existing resources, both tangible and intangible. The calculation of the regression coefficient in this study obtained a value of -0.050 , $\mathrm{t}$-count $-3,321$, which is higher than the significant requirements of the t-table. These results indicate that Human Capital Efficiency (HCE) has a significant effect on return on assets (ROA). The results of this research show that if Islamic banking can carry out maximum human resources efficiency, the company's performance will gradually increase. This is in line with research conducted by Nawaz. (2019) where it was found that there was an influence of Human Capital Efficiency (HCE) on Return On Asset (ROA).

\section{B. Effect of Structure Capital Efficiency on Financial Performance}

The results of the calculation of the regression coefficient in this study obtained a value of 0.013 . The $\mathrm{t}$ count is 3.649 , which is higher than the t-table significant requirement. This research shows that the Structure Capital Efficiency variable has a significant effect on return on assets (ROA). So it can be concluded that the Capital Efficiency Structure affects the financial performance of Islamic banking in Indonesia by using the ROA proxy. The results of this study are in line with research conducted by Nawaz (2019), where the results show that Structure Capital Efficiency influences financial performance.

\section{Effect of Capital Employed Efficiency on Financial Performance}

The calculation of the regression coefficient in this study obtained a value of 0.018 , t-count 2.633 , which is higher than the significant requirements of t-table. These results indicate that the Capital Employed Efficiency variable has a significant effect on return on assets (ROA). So it can be concluded that the Capital Employed Efficiency affects the financial performance of Islamic banking in Indonesia by using the ROA proxy. This study's results are in line with research conducted by Nawaz (2019), where the results show that Structure Capital Efficiency influences financial performance.

\section{CONCLUSSION}

This paper's main contribution is to examine the impact of intellectual capital (IC) on the financial performance of Islamic foreign exchange commercial banks in Indonesia for the period 2013-2019. Our results indicate a significant positive relationship between the performance of the subcomponents of the VAIC, namely HCE, SCE, and CEE, on financial performance. The result shows that the ROA responds to all the sub-components of VAIC. The findings in this study are in line with previous research where Islamic financial institutions are still a fast-growing field. New research is needed to understand the critical dynamics of the way such banking operates in economic networks. 
This study is not without limitations. The main limitation of this study lies in its methodological tool, the VAIC methodology. Pulic (2004) argues that labor costs are to be equated as an investment in a firm's human capital rather than an expense. However, if human capital is seen as an investment, the question arises whether it will be represented as an asset, which Pulic (2004) fails to address. In Pulic's view, human capital is an asset; the cost of labor must be added to the money used to calculate VAIC.

For further researchers, it is hoped that they can look for contingent variables, either moderator or intervening, that can strengthen the relationship between Intellectual Capital and its sub-components with the financial performance of Islamic banking.

\section{REFERENCES}

[1]. Aset Perbankan Syariah Malaysia Capai Rp 2.789 Triliun. (2020, February 4). Republika Online. https://republika.co.id/share/q55xjj383

[2]. Barney, Jay . (1991) "Firm Resources and Sustained Competitive Advantage," Journal of Manajement 17 : 99-120

[3]. Budiasih, IG. A. N. (2015). Intellectual Capital dan Corporate Social Resosibility Pengaruhnya Pada Profitabilitas Perbankan. Jurnal Dinamika Akuntansi, 7(1), 75-84.

[4]. Chen, J., Zhu, Z., \& Yuan Xie, H. (2004). Measuring intellectual capital: A new model and empirical study. Journal of Intellectual Capital, 5(1), 195-212. https://doi.org/10.1108/14691930410513003

[5]. Freeman, R. E. (1999). Response: Divergent Stakeholder Theory. The Academy of Management Review, 24(2), 233. https://doi.org/10.2307/259078

[6]. Hsu, L. C., \& Wang, C. H. (212 C.E.). Clarifying the effect of intellectual capital on performance: The mediating role of dynamic capability. British Journal of Management, 23(2), 179-205.

[7]. Kozlenkova, Irina V. Stephen A. Samaha, dan Robert W. Palmatier. (2013) "Resource-Based Theory in Marketing," Journal of the Academy of Marketing Science 42, no. 1 : $1-21$, https://doi.org/10.1007/s11747-013-0336-7.

[8]. Kusuma, M., \& Rosadi, S. (2019). Islamic Corporate Governance and Islamic Banking Financial Performance. Journal of Finance and Islamic Banking, 1(2), 164-179. https://doi.org/10.22515/jfib.v1i2.1493

[9]. Malik, R. (2015). Bank Peculiar, Macroeconomic Causes and Profitability of Banks: An Evidence from Pakistan. International Journal of Information, Business and Management, 7, 15.

[10]. Mavridis, D. G. (2004). The intellectual capital performance of the Japanese banking sector. Journal of Intellectual Capital, 5(1), 92-115. https://doi.org/10.1108/14691930410512941

[11]. Mediatama, G. (2019, December 11). Alhamdulillah, usai 28 tahun akhirnya pangsa pasar perbankan syariah tembus 6\%-Page all. kontan.co.id. http://keuangan.kontan.co.id/news/alhamdulillah-usai28-tahun-akhirnya-pangsa-pasar-perbankan-syariahtembus-6
[12]. Murthy, V., \& Mouritsen, J. (2011). The Performance of Intellectual Capital: Mobilising Relationships Between Intellectual and Financial Capital in a Bank. Accounting, Auditing and Accountability Journal, 24(5), 622-646. https://doi.org/10.1108/09513571111139120

[13]. Nawaz, T. (2019). Intellectual capital profiles and financial performance of Islamic banks in the UK. International Journal Learning and Intellectual Capital, 16(1), 87-97.

[14]. Nawaz, T., \& Haniffa, R. (2017). Determinants of financial performance of Islamic banks: An intellectual capital perspective. Journal of Islamic Accounting and Business Research, 8(2), 130-142. https://doi.org/10.1108/JIABR-06-2016-0071

[15]. Nurmawati, B. A., Rahman, A. F., \& Baridwan, Z. Z. (2020). The Moderting Role of Intellectual Capital On The Relationship Between Non Profit Sharing Financing, Profit Sharing Financing And Credit Risk To Financial Performance Of Islamic Bank. Jurnal Reviu Akuntansi Dan Keuangan, 10(1), 38-52. https://doi.org/10.22219/jrak.v10i1.10628

[16]. Shehzadi, A., \& Abbas, S. K. (2018). Determinants affecting the economic performance of the banking Sector of Pakistan. Global Scientific Journal, 6(8), 617-635.

[17]. Statistik Perbankan Indonesia. (2019). Otoritas Jasa Keuangan.

[18]. Statistik Perbankan Syariah. (2018). Otoritas Jasa Keuangan.

[19]. Subramanyam, K. R., \& Wild, John. J. (2010). Analisis Laporan Keuangan. Salemba Empat.

[20]. Sudana, I. M. (2019). Manajemen Keuangan Teori dan Praktik. Airlangga University Press.

[21]. Trad, N., Trabelsi, M. A., \& Goux, J. F. (2017). Risk and profitability of Islamic banks: A religious deception or an alternative solution? European Research on Management and Business Economics, 23(1), 40-45.

[22]. Ulum, I. (2009). Intellectual Capital: Konsep dan Kajian Empiris (Pertama). Graha Ilmu.

[23]. Wahyuni, N. K. S., \& Sukartha, I. M. (2019). Pengaruh Good Corporate Governance dan Ukuran Perusahaan Pada Kinerja Keuangan Perusahaan Perbankan. Jurnal Akuntansi, 29(1), 390-404.

[24]. M. Young, The Technical Writer's Handbook. Mill Valley, CA: University Science, 1989. 